\title{
PENGARUH WAKTU DAN SUHU PENGERINGAN TERHADAP KARAKTERISTIK TEH DAUN TIN (FICUS CARICA L.)
}

\author{
EFFECT OF DRYING TIME AND TEMPERATURE ON THE CHARACTERISTICS OF FIG \\ LEAF TEA (FICUS CARICA L.)
}

\author{
Desti Kurnia Sari, Dian Rachmawanti Affandi, Sigit Prabawa \\ Jurusan Ilmu Teknologi Pangan Fakultas Pertanian, Universitas Sebelas Maret, Surakarta
}

Email: destyk18@gmail.com

Diserahkan [30 November 2019]; Diterima [30 Januari 2020]; Dipublikasi [17 Februari 2020]

\begin{abstract}
Fig plants are functional plants. Fig plant leaves have good functional compounds, especially phenolic. Fig leaves can be developed into functional drinks, namely herbal tea. In processing the drying process greatly affects the quality of fig leaf tea. The temperature and time in the drying process are important factors because they can affect the content of functional compounds in fig leaves. The purpose of this study was to determine the effect of temperature and drying time on physical properties (color), chemistry (moisture content, tannin content, total phenol, and antioxidant activity), and sensory (color, smell, taste, and overall) and to know the combination of the temperature and the drying time which results in the best fig leaf tea. The experimental design carried out in this study was a completely randomized design (CRD) with a combination of temperature and drying time. The temperature variations used were $55^{\circ} \mathrm{C}$ and $65^{\circ} \mathrm{C}$ and the time variations used were 4,5 , and 6 (hours). The results showed that the combination treatment of temperature and drying time affected physical and chemical properties, but did not affect the sensory properties of steeping tea except in overall. The best treatment in the drying process of fig leaves is drying at $55^{\circ} \mathrm{C}$ for 4 hours with characteristics: brightness $\left(L^{*}\right)$ 58.107; reddish ( $\left.a^{*}\right)$ 0.103; yellowish $\left(b^{*}\right)$ 16.340; ${ }^{\circ}$ Hue 89.587; moisture content $6.551 \%$; tannin content of $0.258 \%$; total phenol $5.467 \%$; antioxidant activity $40.647 \%$, with appearance yellowish color; the distinctive smell of fig leaves; bitter taste; and overall the panelists accept the level of preference rather dislike.
\end{abstract}

Keywords: drying temperature, drying time, fig leaves, herbal tea

\section{ABSTRAK}

Tanaman tin merupakan tanaman fungsional. Daun tanaman tin memiliki senyawa fungsional yang baik, khususnya fenolik. Daun tin dapat dikembangkan menjadi minuman fungsional yaitu teh herbal. Dalam pengolahannya proses pengeringan sangat mempengaruhi kualitas teh daun tin. Waktu dan suhu dalam proses pengeringan menjadi faktor penting karena dapat mempengaruhi kandungan senyawa fungsional pada daun tin. Tujuan penelitian ini adalah untuk mengetahui pengaruh waktu dan suhu pengeringan terhadap sifat fisik (warna), kimia (kadar air, kadar tanin, total fenol, dan aktivitas antioksidan), dan sensoris (warna, aroma, rasa, dan overall) serta mengetahui kombinasi waktu dan suhu pengeringan yang memberikan hasil teh daun tin terbaik. Rancangan percobaan yang dilakukan pada penelitian ini adalah Rancangan Acak Lengkap (RAL) dengan kombinasi waktu dan suhu pengeringan. Variasi suhu yang digunakan yaitu $55^{\circ} \mathrm{C}$ dan $65^{\circ} \mathrm{C}$ dan variasi waktu yang digunakan yaitu 4, 5, dan 6 (jam). Hasil penelitian menunjukkan bahwa perlakuan kombinasi waktu dan suhu pengeringan mempengaruhi sifat fisik dan kimia, tetapi tidak mempengaruhi sifat sensoris pada seduhan teh daun tin kecuali pada overall. Perlakuan terbaik dalam proses pengeringan daun tin adalah pengeringan dengan suhu $55^{\circ} \mathrm{C}$ selama 4 jam dengan karakteristik: kecerahan ( $\left.\mathrm{L}^{*}\right)$ 58,107; kemerahan (a*) 0,103; kekuningan (b*) 16,340; ${ }^{\circ}$ Hue 89,587; kadar air 6,551\%; kadar tanin 0,258\%; total fenol 5,467\%; aktivitas antioksidan 40,647\%, dengan kenampakan warna kekuningan; aroma khas daun tin; rasa pahit; dan secara overall panelis menerima dengan tingkat kesukaan agak tidak suka.

Kata kunci: daun tin, suhu pengeringan, teh herbal, waktu pengeringan

\section{PENDAHULUAN}

Tanaman tin merupakan salah satu tanaman famili Moraceae yang banyak tersebar luas di daerah tropis maupun subtropis (Patil dan Patil, 2011). Salah satu bagian dari tanaman tin (Ficuscarica L.) yang mudah dimanfaatkan adalah bagian daunnya yang secara tradisional digunakan untuk mengobati berbagai penyakit pada kardiovaskular, saluran pernafasan, gastrointesinal, juga sebagai antispasmodik dan antiinflamasi (Mawa dkk., 2013). Menurut Refli (2012) daun tin memiliki kandungan senyawa alkaloid, saponin, flavonoid dan polifenol. Daun tin dapat diolah menjadi minuman fungsional yaitu teh herbal daun tin. Pada proses pembuatan teh 
kondisi daun, proses pelayuan, proses oksidasi enzimatis, proses pengeringan, dan proses penyeduhan teh diduga dapat mempengaruhi kualitas hasil akhir seduhan teh daun tin. Pada penelitian Laily (2017), diketahui kondisi daun tin terbaik yang dapat digunakan dalam pembuatan teh herbal daun tin yaitu daun normal tidak berkarat. Waktu pelayuan terbaik yang digunakan untuk membuat teh daun tin selama 8 jam. Dari penelitian tersebut, perlu dilakukan penelitian lanjutan untuk mengetahui pengaruh proses pengeringan pada pembuatan teh daun tin untuk menghasilkan teh herbal daun tin dengan kualitas yang baik. Pengeringan bertujuan untuk mengurangi air dari bahan sampai kadar air yang dikehendaki yang berarti mengurangi ketersediaan air untuk pertumbuhan mikroba dan aktivitas enzim (Winarno, 2004). Menurut BSN (2013) kadar air teh kering yang ditetapkan tidak lebih dari $8 \%$.

Dalam proses pengeringan, waktu dan suhu pengeringan diduga dapat mempengaruhi kualitas teh yang dihasilkan. Menurut Winarno (2004), waktu dan suhu pengeringan berpengaruh sangat nyata terhadap aktivitas antioksidan. Menurut Taib dkk. (1997) waktu dan suhu pengeringan diduga dapat mempengaruhi kadar senyawa fungsional yang terdapat dalam daun tin, dapat rusak ataupun berkurang. Waktu dan suhu pengeringan juga diduga dapat mempengaruhi sifat fisik dan sensoris teh daun tin. Menurut Nazaruddin dan Paimin (1993), suhu pengering yang digunakan terlalu tinggi pada daun dalam keadaan basah dapat menyebabkan daun kering pada luarnya saja. Waktu pengeringan yang terlalu lama dapat menyebabkan teh cepat rapuh dan bau serta kualitasnya menurun. Sebaliknya, jika waktu yang digunakan terlalu cepat akan mengakibatkan teh yang dikeringkan tidak cukup kering sehingga tidak dapat disimpan terlalu lama. Menurut Winarno (2004), suhu pengeringan yang terlalu tinggi akan mengakibatkan penurunan nilai gizi danperubahan warna produk yang dikeringkan. Sehingga, perlu dilakukan penelitian untuk mengetahui waktu dan suhu terbaik dalam pengeringan daun tin dalam pembuatan teh herbal daun tin.

\section{METODE PENELITIAN}

\section{Bahan}

Bahan yang digunakan dalam pembuatan teh herbal daun tin adalah daun tin

(Ficus carica L.) varietas Green Yordan dengan kondisi normal tidak berkarat. Daun yang dipetik merupakan daun ke-2 s/d 5 dari ujung tanaman, folin ciocalteu, $\mathrm{Na}_{2} \mathrm{CO}_{3}$, aquades, fenol murni, asam tanat, metanol, DPPH (diphenyl picrylhydrazyl).

\section{Alat}

Alat yang digunakan dibedakan menjadi dua macam, yaitu alat yang digunakan untuk pembuatan teh herbal daun tin adalah timbangan analitik, pisau, tatakan, nampan, baskom, peniris, tray, cabinet dryer, serta alat untuk analisis antara lain chroma meter Konica Minolta Color Reader, botol timbang, oven, desikator, timbangan analitik, penjepit, spektrofotometer UV-Vis, kuvet, pipet volume, propipet, vortex, timbangan analitik, tabung reaksi, rak tabung reaksi, erlenmeyer, gelas ukur, gelas beker, corong, kertas saring, aluminium foil, hotplate, buret, klem, statif, tabung kondensor, selang, ember, labu ukur, nampan, gelas, sendok, kertas label, dan borang.

\section{Tahapan Penelitian}

\section{Pembuatan Teh Daun Tin}

Proses pembuatan teh daun tin diawali dengan memetik daun tin pada tangkai ke-2 s/d 5 dari ujung tanaman tin varietas Green yordan seberat $1 \mathrm{~kg}$ lalu dicuci hingga bersih dengan air yang mengalir. Setelah dicuci, daun ditiriskan lalu dilayukan dengan cara dihamparkan pada lantai yang diberi alas selama 8 jam pada suhu $28-30^{\circ} \mathrm{C}$ dengan dua kali pembalikan daun pada jam ke-3 dan jam ke-6. Setelah dilayukan selama 8 jam, daun tin digulung dan dirajang dengan tebal kurang lebih $0,5 \mathrm{~cm}$. Setelah itu, dilakukan proses oksidasi enzimatis dengan cara dihamparkan pada lantai yang diberi alas selama 2 jam pada suhu $27^{\circ} \mathrm{C}$. Setelah di oksidasi enzimatis, daun dikeringkan dengan alat cabinet dryer dengan suhu $55^{\circ} \mathrm{C}$ dan $65^{\circ} \mathrm{C}$ serta waktu yang digunakan yaitu selama 4 jam, 5 jam, dan 6 jam. Tebal hamparan daun pada rak sekitar $4 \mathrm{~cm}$. 
Setelah kering, 1 gram teh daun tin kering diseduh dengan $200 \mathrm{ml}$ aquades pada suhu $80^{\circ} \mathrm{C}$ (Laily, 2017).

\section{Analisis Fisik, Kimia, dan Organoleptik}

Analisis fisik yang dilakukan yaitu pengukuran warna seduhan teh menggunakan metode Hunter L,a,b. Analisis kimia yang dilakukan yaitu uji kadar air menggunakan metode thermogravimetri, uji kadar tanin dan total fenol menggunakan metode folin ciocalteu, uji aktivitas antioksidan menggunakan metode DPPH, dan uji sensoris menggunakan uji hedonik metode scoring.

\section{Analisis Data}

Pengujian Data yang diperoleh dianalisis dengan metode One Way Analysis of Variances (ANOVA). Bila terdapat perbedaan antar perlakuan maka dilanjutkan dengan uji lanjut Duncan Multiple Range Test (DMRT) pada taraf signifikan 5\% ( $\mathrm{p} \leq$ $0,05)$.

\section{HASIL DAN PEMBAHASAN}

\section{Kemerahan (a*)}

Pemberian perlakuan variasi waktu dan suhu pengeringan berpengaruh terhadap nilai $a^{*}$ pada semua sampel. Nilai a* tertinggi terdapat pada perlakuan F6 yaitu teh dengan pengeringan pada suhu $65^{\circ} \mathrm{C}$ selama 6 jam menghasilkan rata-rata nilai a* sebesar 0,427 dan nilai $a^{*}$ terendah terdapat pada perlakuan F1 yaitu teh dengan pengeringan pada suhu $55^{\circ} \mathrm{C}$ selama 4 jam yang menghasilkan ratarata nilai $a^{*}$ sebesar 0,103 . Semakin tinggi waktu dan suhu pengeringan akan menghasilkan warna seduhan yang semakin cokelat. Dalam penelitian Yamin dkk (2017) semakin lama daun ketepeng cina dikeringkan warna seduhannya menjadi semakin kuning kecokelatan. Perubahan warna tersebut disebabkan karena terjadinya degradasi klorofil menjadi feofitin yang memberikan warna cokelat pada seduhan teh herbal ketepeng cina. Selain feofitin, senyawa thearubigin yang dihasilkan akibat degradasi senyawa tanin menghasilkan warna merah terhadap seduhan teh (Towaha, 2013).

\section{Kekuningan (b*)}

Pemberian perlakuan variasi waktu dan suhu pengeringan berpengaruh terhadap nilai $b^{*}$ pada semua sampel. Nilai $b^{*}$ tertinggi terdapat pada perlakuan $\mathrm{F} 1$ yaitu teh dengan pengeringan pada suhu $55^{\circ} \mathrm{C}$ selama 4 jam menghasilkan rata-rata nilai $b^{*}$ sebesar 16,340 dan nilai $b^{*}$ terendah terdapat pada perlakuan $\mathrm{F} 6$ yaitu teh dengan pengeringan pada suhu $65^{\circ} \mathrm{C}$ selama 6 jam yang menghasilkan rata-rata nilai $b^{*}$ sebesar 14,335. Semakin tinggi waktu dan suhu pengeringan warna kekuningan seduhan teh akan semakin menurun. Menurut Menurut Yamin dkk (2017) semakin lama waktu pengeringan menyebabkan klorofil daun terdegradasi menjadi feofitin yang menyebabkan warna cokelat dan pigmen flavonoida yang menghasilkan warna kuning. Warna kuning yang dihasilkan oleh seduhan teh juga berasal dari senyawa theaflavin yang merupakan hasil degradari senyawa tanin (Towaha, 2013).

Tabel 1 Hasil Analisis Warna Seduhan Teh Daun Tin dengan Perlakuan Variasi Waktu dan Suhu Pengeringan.

\begin{tabular}{ccccc}
\hline Perlakuan & $\mathbf{L}^{*}$ & $\mathbf{a}^{*}$ & $\mathbf{b}^{*}$ & ${ }^{\mathrm{o}}$ Hue \\
\hline F1 & $58,107^{\mathrm{f}} \pm 0,145$ & $0,103^{\mathrm{a}} \pm 0,186$ & $16,340^{\mathrm{f}} \pm 0,651$ & $89,587^{\mathrm{f}} \pm 0,030$ \\
F2 & $57,797^{\mathrm{e}} \pm 0,268$ & $0,197^{\mathrm{b}} \pm 0,186$ & $16,185^{\mathrm{e}} \pm 0,423$ & $89,219^{\mathrm{e}} \pm 0,030$ \\
F3 & $57,125^{\mathrm{b}} \pm 0,160$ & $0,380^{\mathrm{e}} \pm 0,429$ & $14,418^{\mathrm{b}} \pm 0,279$ & $88,668^{\mathrm{b}} \pm 0,600$ \\
F4 & $57,695^{\mathrm{d}} \pm 0,341$ & $0,228^{\mathrm{c}} \pm 0,007$ & $14,825^{\mathrm{d}} \pm 0,383$ & $89,104^{\mathrm{d}} \pm 0,026$ \\
F5 & $57,342^{\mathrm{c}} \pm 0,213$ & $0,297^{\mathrm{d}} \pm 0,281$ & $14,598^{\mathrm{c}} \pm 0,838$ & $88,854^{\mathrm{c}} \pm 0,044$ \\
F6 & $57,045^{\mathrm{a}} \pm 0,193$ & $0,427^{\mathrm{f}} \pm 0,105$ & $14,335^{\mathrm{a}} \pm 0,460$ & $88,490^{\mathrm{a}} \pm 0,038$ \\
\hline
\end{tabular}

Keterangan:

- Notasi yang berbeda baris dan kolom yang sama menunjukkan beda nyata pada $\alpha 0,05$ sig.

- Variasi waktu dan suhu $\mathrm{F} 1=$ waktu 4 jam, suhu $55^{\circ} \mathrm{C} ; \mathrm{F} 2=$ waktu 5 jam, suhu $55^{\circ} \mathrm{C} ; \mathrm{F} 3=$ waktu 6 jam, suhu $55^{\circ} \mathrm{C} ; \mathrm{F} 4=$ waktu 4 jam, suhu $65^{\circ} \mathrm{C} ; \mathrm{F} 5=$ waktu 5 jam, suhu $65^{\circ} \mathrm{C} ; \mathrm{F} 6=$ waktu $6 \mathrm{jam}$, suhu $65^{\circ} \mathrm{C}$. 


\section{${ }^{\circ}$ Hue}

Pemberian perlakuan variasi waktu dan suhu pengeringan berpengaruh terhadap nilai ${ }^{\circ}$ hue pada semua sampel. Nilai ${ }^{\circ}$ hue tertinggi terdapat pada perlakuan $\mathrm{F} 1$ yaitu teh dengan pengeringan pada suhu $55^{\circ} \mathrm{C}$ selama 4 jam menghasilkan rata-rata nilai ${ }^{\circ}$ hue sebesar 89,587 dan nilai ${ }^{\circ}$ hue terendah terdapat pada perlakuan F6 yaitu teh dengan pengeringan pada suhu $65^{\circ} \mathrm{C}$ selama 6 jam yang menghasilkan rata-rata nilai ${ }^{\circ}$ hue sebesar 88,490 . Semakin tinggi waktu dan suhu pengeringan nilai ${ }^{\circ}$ hue semakin menurun. Menurut Lidiasari (2006) waktu pengeringan yang terlalu lama dapat menyebabkan pigmen-pigmen pada bahan mengalami oksidasi menjadi cokelat. Waktu pengeringan yang terlalu lama juga menyebabkan terjadinya perubahan warna bahan serta terjadinya penurunan mutu. Nilai ${ }^{\circ}$ hue dari teh daun tin berkisar antara 88,490 sampai 89,587. Menurut Hutching (1999) kisaran nilai ini menunjukkan bahwa warna teh daun tin berdasarkan ${ }^{\circ}$ hue adalah yellow red.

\section{Karakteristik Kimia Teh Daun Tin (Ficus carica $\mathbf{L}$.)}

\section{Kadar Air}

Pemberian perlakuan variasi waktu dan suhu pengeringan berpengaruh terhadap kadar air pada semua sampel. Kadar air tertinggi terdapat pada perlakuan F1 yaitu teh dengan pengeringan pada suhu $55^{\circ} \mathrm{C}$ selama 4 jam menghasilkan rata-rata nilai kadar air sebesar 6,551\% dan kadar air terendah terdapat pada perlakuan $\mathrm{F} 6$ yaitu teh dengan pengeringan pada suhu $65^{\circ} \mathrm{C}$ selama 6 jam yang menghasilkan rata-rata nilai kadar air sebesar 2,678\%. Semua kadar air sampel teh daun tin telah memenuhi syarat teh kering siap konsumsi menurut BSN (2013) yaitu tidak melebihi dari $8 \%$. Berdasarkan hasil yang diperoleh semakin tinggi waktu dan suhu pengeringan kadar air bahan semakin menurun. Winarno (2004), semakin lama proses pengeringan yang dilakukan, maka panas yang diterima oleh bahan akan lebih banyak sehingga jumlah air yang diuapkan dalam bahan pangan semakin banyak dan kadar air terukur menjadi rendah. Menurut Karina (2008), penguapan terjadi karena perbedaan tekanan uap antara air pada bahan dengan uap air di udara. Tekanan uap air bahan pada umumnya lebih besar dibandingkan dengan tekanan uap udara sehingga terjadi perpindahan massa air dari bahan ke udara. Hal ini berkaitan dengan semakin tinggi suhu pengeringan, maka semakin besar energi panas yang dibawa udara sehingga semakin banyak jumlah massa cairan yang diuapkan dari permukaan bahan yang dikeringkan.

\section{Kadar Tanin}

Pemberian perlakuan variasi waktu dan suhu pengeringan berpengaruh terhadap kadar tanin pada semua sampel. Kadar tanin tertinggi terdapat pada perlakuan $\mathrm{F} 1$ yaitu teh dengan pengeringan pada suhu $55^{\circ} \mathrm{C}$ selama 4 jam yang menghasilkan rata-rata kadar tanin sebesar $0,258 \%$ dan kadar tanin terendah terdapat pada perlakuan $\mathrm{F} 6$ yaitu teh dengan pengeringan pada suhu $65^{\circ} \mathrm{C}$ selama 6 jam yang menghasilkan rata-rata kadar tanin sebesar $0,150 \%$. Berdasarkan hasil yang diperoleh semakin tinggi waktu dan suhu pengeringan maka nilai tanin teh yang dihasilkan akan semakin rendah. Menurut Sekarini (2011), tanin memiliki senyawa epigalokatekingalat yang merupakan penyusun flavonoid yang berperan sebagai antioksidan terbesar selain querecetin pada senyawa flavanol. Komponen tanin ini akan mengalami banyak perubahan kimia pada suhu tinggi. Peristiwa oksidasi tanin dipengaruhi oleh adanya oksigen, $\mathrm{pH}$ larutan, cahaya, dan adanya bahan antioksidan. Komponen epigallokatekin dan galat pada teh akan teroksidasi membentuk ortoquinon dan selanjutnya akan mengalami kondensasi dengan adanya molekul hidrogen, sehingga membentuk bisflavanol. Kemudian, komponen bisflavanol yang terbentuk akan terkondensasi membentuk theaflavin dan thearubigin yang mempunyai kandungan polifenol lebih rendah. 
Tabel 2 Karakteristik Kimia Teh Daun Tin dengan Perlakuan Variasi Waktu dan Suhu Pengeringan.

\begin{tabular}{ccccc}
\hline Perlakuan & $\begin{array}{c}\text { Kadar air** } \\
(\boldsymbol{\%})\end{array}$ & $\begin{array}{c}\text { Nilai Tanin* } \\
(\boldsymbol{\%})\end{array}$ & $\begin{array}{c}\text { Total Fenol* } \\
(\boldsymbol{\%})\end{array}$ & $\begin{array}{c}\text { Aktivitas } \\
\text { Antioksidan }^{*}(\boldsymbol{\%})\end{array}$ \\
\hline F1 & $6,551^{\mathrm{f}} \pm 0,234$ & $0,258^{\mathrm{f}} \pm 0,006$ & $5,467^{\mathrm{f}} \pm 0,027$ & $40,647^{\mathrm{f}} \pm 0,154$ \\
F2 & $5,369^{\mathrm{e}} \pm 0,179$ & $0,213^{\mathrm{e}} \pm 0,004$ & $4,954^{\mathrm{e}} \pm 0,022$ & $38,881^{\mathrm{e}} \pm 0,154$ \\
F3 & $3,006^{\mathrm{b}} \pm 0,119$ & $0,181^{\mathrm{b}} \pm 0,007$ & $3,964^{\mathrm{b}} \pm 0,032$ & $36,617^{\mathrm{b}} \pm 0,147$ \\
F4 & $4,925^{\mathrm{d}} \pm 0,236$ & $0,203^{\mathrm{d}} \pm 0,006$ & $4,780^{\mathrm{d}} \pm 0,054$ & $38,159^{\mathrm{d}} \pm 0,082$ \\
F5 & $4,256^{\mathrm{c}} \pm 0,167$ & $0,184^{\mathrm{c}} \pm 0,004$ & $4,411^{\mathrm{c}} \pm 0,042$ & $37,786^{\mathrm{c}} \pm 0,077$ \\
F6 & $2,678^{\mathrm{a}} \pm 0,111$ & $0,150^{\mathrm{a}} \pm 0,009$ & $3,786^{\mathrm{a}} \pm 0,020$ & $33,930^{\mathrm{a}} \pm 0,122$ \\
\hline
\end{tabular}

Keterangan:

- Notasi yang berbeda baris dan kolom yang sama menunjukkan beda nyata pada $\alpha 0,05 \mathrm{sig}$.

- Variasi waktu dan suhu $\mathrm{F} 1=$ waktu 4 jam, suhu $55^{\circ} \mathrm{C} ; \mathrm{F} 2=$ waktu 5 jam, suhu $55^{\circ} \mathrm{C} ; \mathrm{F} 3=$ waktu 6 jam, suhu $55^{\circ} \mathrm{C} ; \mathrm{F} 4=$ waktu 4 jam, suhu $65^{\circ} \mathrm{C} ; \mathrm{F} 5=$ waktu 5 jam, suhu $65^{\circ} \mathrm{C} ; \mathrm{F} 6=$ waktu 6 jam, suhu $65^{\circ} \mathrm{C}$.

- *seduhan teh daun tin, **teh kering daun tin

\section{Total Fenol}

Pemberian perlakuan variasi waktu dan suhu pengeringan berpengaruh terhadap kadar total fenol pada semua sampel. Kadar total fenol tertinggi terdapat pada perlakuan F1 yaitu teh dengan pengeringan pada suhu $55^{\circ} \mathrm{C}$ selama 4 jam menghasilkan rata-rata kadar total fenol sebesar 5,467\% dan kadar total fenol terendah terdapat padap perlakuan F6 yaitu teh dengan pengeringan pada suhu $65^{\circ} \mathrm{C}$ selama 6 jam yang menghasilkan ratarata kadar total fenol sebesar 3,786\%. Berdasarkan hasil yang diperoleh semakin tinggi waktu dan suhu pengeringan kadar total fenol teh yang dihasilkan akan semakin menurun. Menurut Permata (2015) pengeringan dapat merusak beberapa senyawa fenol, sehingga semakin tinggi suhu pengeringan kadar fenoliknya akan semakin menurun. Kadar total fenol berbanding lurus dengan aktivitas antioksidan terbukti semakin tinggi suhu pengeringan maka aktivitas antioksidan juga semakin menurun. Menurut Yuliawaty dan Susanto (2015) kadar total fenol menurun seiring dengan meningkatnya lama waktu pengeringan daun mengkudu disebabkan karena adanya proses oksidasi akibat adanya perlakuan panas, sehingga adanya proses pengeringan dapat menurunkan kandungan senyawa fenol pada daun.

\section{Aktivitas Antioksidan}

Pemberian perlakuan variasi waktu dan suhu pengeringan berpengaruh terhadap aktivitas antioksidan pada semua sampel. Aktivitas antioksidan tertinggi terdapat pada perlakuan $\mathrm{F} 1$ yaitu teh dengan pengeringan pada suhu $55^{\circ} \mathrm{C}$ selama 4 jam menghasilkan rata-rata aktivitas antioksidan sebesar 40,647\% dan aktivitas antioksidan terendah terdapat pada perlakuan F6 yaitu teh dengan pengeringan pada suhu $65^{\circ} \mathrm{C}$ selama 6 jam yang menghasilkan rata-rata nilai antioksidan sebesar 33,930\%. Semakin lama proses pengeringan dan semakin panas suhu pengeringan maka aktivitas antioksidan pada teh akan semakin menurun (Apriadji, 2008 dalam Rusnayanti, 2018). Menurut Sekarini (2011) penurunan aktivitas antioksidan dipengaruhi oleh banyaknya kadar tanin dari senyawa flavonoid yang terlarut, sebab epigallokatekingallat pada tanin merupakan senyawa penyusun flavonoid yang berperan sebagai antioksidan terbesar selain querecetin pada senyawa flavanol. Menurut Mahmoudi dkk (2010) aktivitas antioksidan dipengaruhi oleh senyawa fenolik. Senyawa fenol berfungsi sebagai antioksidan karena memiliki kemampuan untuk menstabilkan radikal bebas dengan atom hidrogen (Suryatno dkk., 2012). Hal ini dikarenakan antioksidan akan rusak oleh panas dan pemasakan. Rahayu dkk. (2009) juga menyatakan bahwa bunga rosella yang mengalami proses pengeringan, akivitas antioksidan yang dihasilkan akan lebih kecil. Hal ini disebabkan karena terjadi degradasi atau kerusakan senyawa antioksidan bunga rosella selama proses pengeringan. 


\section{Karakteristik Sensoris Seduhan Teh Daun Tin (Ficus carica L.)}

Tabel 3 Skor Tingkat Kesukaan pada Berbagai Parameter Teh terhadap Seduhan Teh Daun Tin dengan Perlakuan Variasi Waktu dan Suhu Pengeringan.

\begin{tabular}{ccccc}
\hline Perlakuan & Warna & Aroma & Rasa & Overall \\
\hline F1 & $3,98^{\mathrm{a}} \pm 0,771$ & $3,67^{\mathrm{a}} \pm 0,715$ & $3,58^{\mathrm{a}} \pm 0,763$ & $3,67^{\mathrm{a}} \pm 0,715$ \\
F2 & $3,98^{\mathrm{a}} \pm 0,672$ & $3,79^{\mathrm{a}} \pm 0,742$ & $3,70^{\mathrm{a}} \pm 0,708$ & $3,67^{\mathrm{a}} \pm 0,747$ \\
F3 & $3,72^{\mathrm{a}} \pm 0,701$ & $3,63^{\mathrm{a}} \pm 0,618$ & $3,60^{\mathrm{a}} \pm 0,728$ & $3,58^{\mathrm{a}} \pm 0,663$ \\
F4 & $3,95^{\mathrm{a}} \pm 0,815$ & $3,93^{\mathrm{a}} \pm 0,799$ & $3,88^{\mathrm{a}} \pm 0,731$ & $4,14^{\mathrm{b}} \pm 0,743$ \\
F5 & $3,95^{\mathrm{a}} \pm 0,754$ & $3,93^{\mathrm{a}} \pm 0,737$ & $3,77^{\mathrm{a}} \pm 0,751$ & $4,02^{\mathrm{b}} \pm 0,707$ \\
F6 & $3,65^{\mathrm{a}} \pm 0,573$ & $3,63^{\mathrm{a}} \pm 0,578$ & $3,84^{\mathrm{a}} \pm 0,785$ & $3,56^{\mathrm{a}} \pm 0,765$ \\
\hline
\end{tabular}

Keterangan:

- Notasi yang berbeda baris dan kolom yang sama menunjukkan beda nyata pada $\alpha 0,05$ sig.

- Variasi waktu dan suhu $\mathrm{F} 1=$ waktu $4 \mathrm{jam}$, suhu $55^{\circ} \mathrm{C} ; \mathrm{F} 2=$ waktu $5 \mathrm{jam}$, suhu $55^{\circ} \mathrm{C}$; F3= waktu 6 jam, suhu $55^{\circ} \mathrm{C}$; F4= waktu 4 jam, suhu $65^{\circ} \mathrm{C}$; F5 = waktu 5 jam, suhu $65^{\circ} \mathrm{C}$; F6= waktu 6 jam, suhu $65^{\circ} \mathrm{C}$.

- Skor tingkat kesukaan $1=$ sangat tidak suka, $2=$ agak suka, $3=$ agak tidak suka, $4=$ agak suka, $5=$ suka, $6=$ sangat suka.

\section{Warna}

Pemberian perlakuan variasi waktu dan suhu pengeringan tidak berpengaruh pada skor kesukaan terhadap parameter warna seduhan teh daun tin. Nilai kesukaan panelis terhadap warna teh daun tin berkisar antara 3,65-3,98. Berdasarkan hasil pengamatan kenampakan warna seduhan teh daun tin dengan perlakuan waktu dan suhu yang berbeda memiliki warna yang cenderung sama yaitu berwarna kuning kecokelatan. Namun, semakin tinggi waktu dan suhu pengeringan warna seduhan terlihat sedikit semakin cokelat. Warna yang dihasilkan semua seduhan teh daun tin yang cenderung berwarna kuning kecokelatan diduga sebagai penyebab tidak berpengaruhnya perlakuan yang berbeda terhadap tingkat kesukaan panelis terhadap warna seduhan teh daun tin.

Warna teh dipengaruhi oleh pigmen warna pada daun seperti klorofil dan karotenoid dan juga kandungan tanin didalamnya (Winarno, 2004). Menurut Nafisah dan Widyaningsih (2018) suhu pengeringan mempengaruhi kenampakan warna pada seduhan teh yang mana dalam pembuatan minuman fungsional daun cascara semakin tinggi suhu pengeringan, warna seduhan teh yang dihasilkan akan semakin gelap. Menurut Adri dan Hersoelistyorini (2013) proses pengeringan menyebabkan warna hijau klorofil pada daun teroksidasi menjadi cokelat yang disebut peristiwa pencokelatan. Selain klorofil, tanin juga mengalami oksidasi yang akan menghasilkan senyawa theaflavin yang menghasilkan warna kuning dan thearubigin yang menghasilkan warna merah, semakin lama teroksidasi senyawa thearubigin semakin meningkat seiring menurunnya konsentrasi polifenol sehingga warna seduhan teh akan semakin gelap (Towaha, 2013).

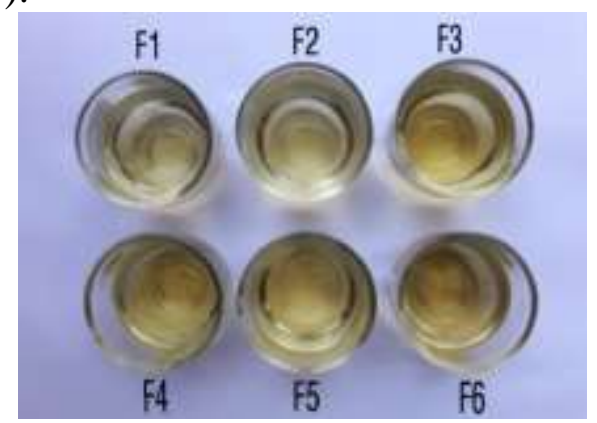

Gambar 1. Kenampakan Warna Seduhan Teh Daun Tin dengan Berbagai Perlakuan.

\section{Aroma}

Pemberian perlakuan variasi waktu dan suhu pengeringan tidak berpengaruh pada skor kesukaan terhadap parameter aroma seduhan teh daun tin. Nilai kesukaan panelis terhadap aroma teh daun tin berkisar antara 3,63-3,93. Dari hasil pengamatan, aroma yang muncul dari seduhan teh daun tin dengan perlakuan variasi waktu dan suhu pengeringan yang berbeda memiliki aroma yang cenderung sama yaitu beraroma khas daun tin. Aroma yang dihasilkan semua seduhan teh daun tin yang cenderung sama beraroma khas daun tin diduga sebagai penyebab tidak berpengaruhnya perlakuan yang berbeda terhadap tingkat kesukaan panelis terhadap aroma seduhan teh daun tin. Menurut Ciptadi dan Nasution (1979) 
senyawa pembentuk aroma teh terutama terdiri dari minyak atsiri yang bersifat mudah menguap dan mudah direduksi sehingga dapat menghasilkan aroma yang harum. Semakin lama waktu pengeringan dapat mempengaruhi warna dan aroma teh. Menurut Adri dan Hersoelistyorini (2013) proses pengeringan mengakibatkan senyawa katekin pada tanin teroksidasi menjadi thearubigin yang menghaslkan aroma harum pada teh.

\section{Rasa}

Pemberian perlakuan variasi waktu dan suhu pengeringan tidak berpengaruh pada skor kesukaan terhadap parameter rasa seduhan teh daun tin. Nilai kesukaan panelis terhadap rasa teh daun tin berkisar antara 3,58-3,88. Dari hasil pengamatan, rasa seduhan teh daun tin dengan perlakuan variasi waktu dan suhu pengeringan menghasilkan rasa yang cenderung sama yaitu berasa pahit dan sepat. Namun, semakin tinggi waktu dan suhu pengeringan intensitas rasa pahitnya semakin menurun. Rasa yang dihasilkan semua seduhan teh daun tin yang cenderung sama berasa sepat diduga sebagai penyebab tidak berpengaruhnya perlakuan yang berbeda terhadap tingkat kesukaan panelis terhadap rasa seduhan teh daun tin.

Menurut Sekarini (2011) tanin merupakan senyawa yang dapat menentukan kualitas teh yang berkaitan dengan warna, rasa dan aroma pada teh. Katekin pada tanin ini memiliki sifat tidak berwarna hingga kekuning-kuningan, larut dalam air, serta membawa sifat pahit dan sepat pada seduhan teh. Adanya senyawa tanin dalam bahan makanan dapat menentukan cita rasa bahan makanan tersebut. Rasa sepat bahan makanan biasanya disebabkan oleh tanin. Kandungan tanin dalam teh dapat digunakan sebagai pedoman mutu, karena tanin juga memberikan kemantapan rasa. Sifat tanin pada tumbuh-tumbuhan tergantung pada gugus fenolik- $\mathrm{OH}$ yang terkandung dalam tanin (Kartasapoetro, 1992 dalam Siregar, 2009).

\section{Overall}

Pemberian perlakuan variasi waktu dan suhu pengeringan berpengaruh pada skor kesukaan terhadap parameter overall seduhan teh daun tin. Nilai kesukaan panelis terhadap parameter overall teh daun tin berkisar antara $3,56-4,14$. Rata-rata skor kesukaan panelis tertinggi pada parameter overall ini sebesar 4,14 pada perlakuan $\mathrm{F} 4$ yaitu teh yang dikeringkan dengan suhu $65^{\circ} \mathrm{C}$ dan waktu 4 jam. Pada perlakuan F4 juga memiliki skor tingkat kesukaan tertinggi pada parameter rasa dan aroma. Rasa dan aroma pada seduhan teh daun tin diduga mempengaruhi tingkat kesukaan panelis terhadap parameter overall sehingga perlakuan F4 memiliki skor kesukaan tertinggi pada parameter overall.

\section{Pemilihan Perlakuan Terbaik}

Pemilihan perlakuan terbaik dilakukan berdasarkan hasil analisis fisik, kimia, dan sensoris yang telah dilakukan pada pemberian variasi waktu dan suhu pengeringan teh daun tin. Pemilihan produk terbaik ini mengacu pada Sullivan dkk. (2015) menggunakan compensatory modeldengan metode nondimensional scaling yang bertujuan untuk menghilangkan faktor adanya satuan pada setiap data. Dengan metode ini data yang telah dianalisis yang memiliki satuan yang berbeda akan diubah ke dalam bentuk non dimensional sehingga data yang berbeda tersebut dapat dibandingkan secara setara. Analisis perhitungan dalam menentukan perlakuan terbaik dilakukan dengan menentukan terlebih dahulu nilai terbaik dan terburuk pada setiap parameter. Setelah data ditentukan, dilanjutkan dengan pemberian bobot pada setiap parameter yang disebut juga dengan bobot variabel atau variable weight (VW). Skala bobot yang digunakan berkisar $0-1$. Pembobotan dilakukan sesuai dengan tingkat kepentingan parameter tertentu yang lebih diprioritaskan dalam menentukan produk terbaik. Setelah dihitung bobot masing-masing, dilakukan perhitungan total nilai dalam menentukan perlakuan produk terbaik. Hasil perhitungan total nilai dalam menentukan perlakuan produk terbaik disajikan pada Tabel 4. 
Tabel 4 Perhitungan Penilaian Terbaik Teh Daun Tin

\begin{tabular}{|c|c|c|c|c|c|c|c|c|c|c|c|c|c|}
\hline \multirow[t]{2}{*}{ Karakteristik } & \multirow[t]{2}{*}{ NW } & \multicolumn{2}{|c|}{ F1 } & \multicolumn{2}{|c|}{ F2 } & \multicolumn{2}{|c|}{ F3 } & \multicolumn{2}{|c|}{ F4 } & \multicolumn{2}{|c|}{ F5 } & \multicolumn{2}{|c|}{ F6 } \\
\hline & & NV & Skor & NV & Skor & NV & Skor & NV & Skor & NV & Skor & NV & Skor \\
\hline \multicolumn{14}{|l|}{ Fisik } \\
\hline $\mathrm{L}^{*}$ & 0,063 & 1,000 & 0,063 & 0,708 & 0,045 & 0,075 & 0,005 & 0,612 & 0,039 & 0,280 & 0,018 & 0,000 & 0,000 \\
\hline$a^{*}$ & 0,063 & 0,000 & 0,000 & 0,290 & 0,018 & 0,855 & 0,054 & 0,386 & 0,024 & 0,599 & 0,038 & 1,000 & 0,063 \\
\hline$b^{*}$ & 0,063 & 1,000 & 0,063 & 0,923 & 0,059 & 0,041 & 0,003 & 0,244 & 0,016 & 0,131 & 0,008 & 0,000 & 0,000 \\
\hline${ }^{\circ} \mathrm{Hue}$ & 0,095 & 1,000 & 0,095 & 0,665 & 0,063 & 0,162 & 0,015 & 0,560 & 0,053 & 0,332 & 0,032 & 0,000 & 0,000 \\
\hline \multicolumn{14}{|l|}{ Kimia } \\
\hline Kadar Air & 0,159 & 0,000 & 0,000 & 0,305 & 0,048 & 0,915 & 0,145 & 0,420 & 0,067 & 0,593 & 0,094 & 1,000 & 0,159 \\
\hline Total Fenol & 0,159 & 1,000 & 0,159 & 0,695 & 0,110 & 0,106 & 0,017 & 0,591 & 0,094 & 0,372 & 0,059 & 0,000 & 0,000 \\
\hline Kadar Tanin & 0,159 & 1,000 & 0,159 & 0,583 & 0,093 & 0,287 & 0,046 & 0,491 & 0,078 & 0,315 & 0,050 & 0,000 & 0,000 \\
\hline $\begin{array}{l}\text { Aktivitas } \\
\text { Antioksidan }\end{array}$ & 0,159 & 1,000 & 0,159 & 0,737 & 0,117 & 0,408 & 0,065 & 0,630 & 0,100 & 0,574 & 0,091 & 0,000 & 0,000 \\
\hline \multicolumn{14}{|l|}{ Sensoris } \\
\hline & 0,000 & 1,000 & 0,000 & 1,000 & 0,000 & 0,212 & 0,000 & 0,909 & 0,000 & 0,909 & 0,000 & 0,000 & 0,000 \\
\hline Aroma & 0,000 & 0,133 & 0,000 & 0,533 & 0,000 & 0,000 & 0,000 & 1,000 & 0,000 & 1,000 & 0,000 & 0,000 & 0,000 \\
\hline Rasa & 0,000 & 0,000 & 0,000 & 0,400 & 0,000 & 0,067 & 0,000 & 1,000 & 0,000 & 0,633 & 0,000 & 0,867 & 0,000 \\
\hline Overall & 0,079 & 0,190 & 0,015 & 0,190 & 0,015 & 0,034 & 0,003 & 1,000 & 0,079 & 0,793 & 0,063 & 0,000 & 0,000 \\
\hline TOTAL & 1,000 & & 0,713 & & 0,569 & & 0,352 & & 0,550 & & 0,453 & & 0,222 \\
\hline
\end{tabular}

Keterangan:

- Variasi waktu dan suhu $\mathrm{F} 1=$ waktu 4 jam, suhu $55^{\circ} \mathrm{C} ; \mathrm{F} 2=$ waktu 5 jam, suhu $55^{\circ} \mathrm{C} ; \mathrm{F} 3=$ waktu 6 jam, suhu $55^{\circ} \mathrm{C}$; F4= waktu 4 jam, suhu $65^{\circ} \mathrm{C}$; F5= waktu 5 jam, suhu $65^{\circ} \mathrm{C}$; F6= waktu 6 jam, suhu $65^{\circ} \mathrm{C}$.

- VW: Variable Weight (bobot variabel), NW: Normalization Weight (nilai normal), NV: Nondimentional Value

Dilihat dari karakteristik fisik dan kimia yang tidak dapat terdeteksi secara langsung oleh panelis, perlakuan pengeringan suhu $55^{\circ} \mathrm{C}$ dan waktu 4 jam memiliki nilai tertinggi pada uji kadar tanin, total fenol dan aktivitas antioksidan yang telah dilakukan. Sementara dilihat dari analisis sensoris yang diperoleh tidak ditemukan perbedaan antar sampel dalam parameter warna, aroma dan rasa. Berdasarkan perhitungan dengan pembobotan, dilihat dari total skor tertinggi pada Tabel 4. diperoleh produk terbaik yaitu teh daun tin dengan pengeringan suhu $55^{\circ} \mathrm{C}$ dan waktu 4 jam. Untuk mendapatkan seduhan teh daun tin dengan nilai fungsional yang baik pada perlakuan terbaik, perlu dilakukan pengujian lanjutan untuk mengetahui lama umur simpan teh tersebut agar dapat mengetahui berapa lama teh tersebut dapat menjaga kandungan senyawa fungsional yang ada di dalamnya.

\section{KESIMPULAN}

Berdasarkan hasil penelitian "Pengaruh Variasi Waktu dan Suhu Pengeringan terhadap Karakteristik Teh Daun Tin (Ficus carica L.)" dapat diambil kesimpulan bahwa semakin tinggi waktu dan suhu pengeringan menghasilkan nilai kecerahan ( $\left.\mathrm{L}^{*}\right)$ yang semakin rendah, nilai kemerahan $\left(\mathrm{a}^{*}\right)$ semakin tinggi, nilai kekuningan $\left(b^{*}\right)$ semakin rendah dan nilai ${ }^{\circ}$ hue semakin rendah. Semakin tinggi waktu dan suhu pengeringan menghasilkan kadar air, kadar tanin, total fenol, dan aktivitas antioksidan semakin menurun.

Variasi waktu dan suhu pengeringan tidak mempengaruhi kesukaan panelis terhadap warna, aroma, dan rasa seduhan teh daun tin, namun mempengaruhi kesukaan panelis terhadap overall seduhan teh daun tin. Teh daun tin terbaik adalah teh yang dikeringkan pada suhu $55^{\circ} \mathrm{C}$ selama 4 jam.

\section{DAFTAR PUSTAKA}

Adri, Delvi dan Wikanastri Hersoelistyorini. 2013. Aktivitas Antioksidan dan Sifat Organoleptik Teh Daun Sirsak (Annona muricata Linn.) Berdasarkan Variasi Lama Pengeringan. Jurnal Pangan dan Gizi Vol.4 (7) hal:1-7. 
BSN (Badan Standarisasi Nasional). 2013. SNI-3836-2013. Persyaratan mutu teh kering dalam kemasan. Jakarta.

Ciptadi, W. dan M. Z. Nasution. 1979. Mempelajari Cara Pemanfaatan The Hitam Mutu Rendah untuk Pembuatan Teh Dadak. IPB. Bogor.

Hutching, J.B. 1999. Food Colour and Appearance. Aspen Publisher. Maryland.

Karina, Anita. 2008. Pemanfaatan Jahe (Zingiber Officinale Rosc.) dan Teh Hijau (Camellia Sinensis) dalam Pembuatan Selai Rendah Kalori dan Sumber Antioksidan. Skripsi Fakultas Pertanian. IPB. Bogor.

Laily, Fakhria Nur. 2017. Pengaruh Lama Pelayuan dan Kondisi Daun Terhadap Karakteristik Fisik, Kimia, Serta Sensoris Teh Daun Tin (Ficus carica). Skripsi Ilmu dan Teknologi Pangan. Fakultas Pertanian Universitas Sebelas Maret. Surakarta.

Lidiasari. E., Syafutri M.I., dan Syaiful. F. 2006. Pengaruh Perbedaan Suhu Pengeringan Tepung Tapai Ubi Kayu Terhadap Mutu Fisik dan Kimia yang Dihasilkan. Jurnal Ilmu-ilmu Pertanian Indonesia Inderalaya. Vol. 7 hal: 28-35.

Mahmoudi, S., Khali, M., Benkhaled, A., Benamirouche K. and Baiti, I..2016. Phenolic and Flavonoid Contents, Antioxidant and Antimicrobial Activities of Leaf Extracts from Ten Algerian Ficus carica L. Varieties. Asian Pacific Journal of Tropical Biomedicine Vol.6 (3).

Mawa, S., Husain, K. danJantan, I..2013. Review Article Ficus carica L. (Moraceae): Phytochemistry, Traditional Uses and Biological Activities. Hindawi Publishing Corporation Evidence-Based Complementary and Alternative Medicine Volume 2013. Drug and Herbal Research Centre, Faculty of Pharmacy, Universiti Kebangsaan Malaysia, Jalan Raja Muda Abdul Aziz, 50300 Kuala Lumpur, Malaysia.

Nafisah, Dzurratun dan Tri Dewanti Widyaningsih. 2018. Kajian Metode
Pengeringan dan Rasio Penyeduhan pada Proses Pembuatan Teh Cascara Kopi Arabika (Coffea Arabika L.). Jurnal Pangan dan Agroindustri Vol.6 (3) hal: 37-47.

Nazaruddin dan Paimin F.B. 1993. Pembudidayaan dan Pengolahan Teh. Penebar Swadaya. Jakarta.

Patil, Vikas V. dan Vijay R. Patil. 2011. Ficuscarica Linn.-an overview.Res Journal Med Plants Vol.5 (3) page:246253.

Permata, D. 2015. Aktivitas Inhibisi Amilase dan Total Polifenol Teh Daun Sisik Naga Pada Suhu Dan Pengeringan Yang Berbeda. Seminar agroindustri dan lokakarya nasional FKPT-TPI, 2-3 September 2015. Universitas Andalas.

Rahayu, Wiranti Sri, Dwi Hartanti, dan Nasrun Hidayat. 2009. Pengaruh Metode Pengeringan Terhadap Kadar Antosian Pada Kelopak Bunga Rosela (Hibiscus sabdariffa L.). Jurnal Pharmacy Vol. 6 (02).

Refli, R. 2012. Potensi Ekstrak Daun Tin (Ficus carica L.) Sebagai Antioksidan dan Aktivitas Hambatannya Terhadap Poliferasi Sel Kanker HeLa. Skripsi Departemen Kimia, Fakultas Matematika dan Ilmu Pengetahuan Alam. Institut Pertanian Bogor. Bogor.

Rusnayanti, Yunita. 2018. Pengaruh Suhu dan Lama Pengeringan Terhadap Mutuh Teh Hijau Daun Kakao (Theobroma cacao L.). Skripsi Fakultas Teknologi Pangan dan Agroindustri Mataram. Mataram.

Sekarini, Gandes Ayu. 2011. Kajian Penambahan Gula dan Suhu Penyajian Terhadap Kadar Total Fenol, Kadar Tanin (Katekin) dan Aktivitas Antioksidan pada Minuman The Hijau (Camellia sinensis L.). Skripsi Jurusan Teknologi Hasil Pertanian. Universitas Sebelas Maret. Surakarta.

Siregar, Nurdiansyah. 2009. Pengaruh Lamanya Perendaman Daun Teh Terhadap Kadar Tanin Beverage Di PT. Coca-Cola Botling Indonesia Medan. Karya Ilmiah Program Studi DIII Kimia Analisis Pengetahuan Alam. Universitas Sumatera Utara. Medan. 
Sullivan, W.G., Wicks, E.M., Koeling, C.P. 2015. Engenering Economy (Sixteentg Edition). Pearson. New Jersey.

Suryatno, H. Basito, Widowati, E. 2012. Kajian Organoleptik, Aktivitas Antioksidan, Total Fenol Pada Variasi Lama Pemeraman Pembuatan Telur Asin yang Ditambah Ekstrak Jahe (Zingiber officinale Roscoe). Jurnal Teknosains Pangan Vol.1 (1).

Sofia, D. 2006. Antioksidan dan Radikal. www.chem-is.try.com. (Diakses tanggal 12 Mei 2019).

Taib, G., Said G. dan Wiraatmadja S.. 1988. Operasi Pengeringan pada pengolahan Hasil Pertanian. Mediyatama Sarana Perkaya. Jakarta.

Towaha, J. 2013. Kandungan Senyawa Kimia Pada Daun Teh (Camellia sinensis). Warta Penelitian dan Pengembangan Tanaman Industri Vol.19.

Winarno, F.G. 2004.Kimia Pangan dan Gizi. PT. Gramedia Pustaka Utama. Jakarta.

Yamin, Muhammad, Dewi Furtuna, dan Faizah Hamzah. 2017. Lama Pengeringan Terhadap Aktivitas Antioksidan dan Mutu Teh Herbal Daun Ketepeng Cina (Cassia alata L.). Jurnal FAPERTA Vol. 4 (2) hal: 1-15.

Yuliawaty, Siska Tresna dan Wahono Hadi Susanto. 2015. Pengaruh Lama Pengeringan dan Konsentrasi Maltodekstrin Terhadap Karakteristik Fisik Kimia dan Organoleptik Minuman Instan Daun Mengkudu (Morinda Citrifolia L). Jurnal Pangan dan Agroindustri Vol. 3 (1). 